UDC 633.88:576.8

\title{
STUDY OF THE COMPOSITION OF EXTRACT AND ANTIMYCOTIC PROPERTIES ANTHEMIS ALTISSIMA L.
}

\author{
(C) S.J. Mustafayeva ${ }^{1}$, S.V. Serkerov ${ }^{I^{*}}$, K.F. Bakhshaliyeva ${ }^{2}$ \\ 1 Institute of Botany of Azerbaijan National Academy of Sciences, \\ Badamdar ave., 40, Baku, Az1073 (Azerbaijan), e-mail: s.serkerov@mail.ru \\ 2 Institute of Microbiology of Azerbaijan National Academy of Sciences, \\ Badamdar ave. 40, Baku, Az1073 (Azerbaijan)
}

The qualitative and quantitative composition of chemical components of ethanol extract of the above-ground part of Anthemis altissima L. (syn. Cota altissima (L.) J.Gay) species (family Asteraceae) collected during flowering phase from the flora of Azerbaijan has been studied.

The chemical composition of ethanol extract was analyzed by chromatography-mass-spectrometry methods. 54 components were identified in the extract. As a result of the study, it was found that the A. altissima contained benzene aromatic compounds (77.21\%). Among them Benzene, (1-butylheptyl) - 7.84\%, Benzene, (1-propyloctyl) - 7.71\%, Benzene, (1-pentyloctyl) $-7.03 \%$, Benzene, (1-pentylheptyl) - 5.69\%, Benzene, (1-butyloctyl) - 5.37\%, Benzene, (1-propylnonyl) - 5.02\% were the main components.

In addition to the above components in the extract of the aerial part other biological active substances, such as alcohols $(6.37 \%$ - of them prevail Hop-22(29)-en-3. $\beta$.-ol - 1.53\%, $\gamma$-Sitosterol - 1.32\%), esters of acids $(5.3 \%$ - of them prevail Hexadecanoic acid, ethyl ester $-0.88 \%$; Linoleic acid, ethyl ester $-0.63 \%)$ and alkanes $(1.64 \%$ - of them prevail Eicosane $-0.53 \%$; Pentacosane $-0.40 \%$ ) were also identified. The share of unidentified components was $8.99 \%$.

The article also presents the results of the study of the antifungal properties of $A$. altissima and its aqueous extract against the culture of pathogenic fungi Fusarium oxysporium and Aspergillus niger. The aqueous extract of A. altissima, in contrast to the plant itself, shows a fungistatic effect on the fungi Fusarium oxysporum and Aspergillus niger.

Keywords: Anthemis altissima; extract; chromatography-mass-spectrometry; biological active compounds; antifungal; cultures of pathogenic fungi Fusarium oxysporium and Aspergillus niger.

\section{Introduction}

The genus Anthemis L. of the tribes Anthemideae Cass. of the families Asteraceae Bercht. et J. Presl breed is recognized up to 210 species spread throughout Europe, the Mediterranean, West Asia, and Africa. Anthemis taxa have been commonly used as folk medicine, insecticides and ornamental plant from ancient times up to now. Anthemis is probably, in a phytochemical sense, one of the most repeatedly investigated genera of the Asteraceae family. A lot of work has been done on sesquiterpene lactones, polyacetylenes, flavonoids, essential oils [1-15]. Essential oils from flowers Anthemis is very useful for pharmaceuticals, and food additives, as well as important sources in food, aromatic and cosmetic industries. The species Anthemis has been studied on the chemical composition and diverse biological activities, such as their antioxidant, antifungal, antiplasmodial, antitumor, schistosomicidal, cytotoxic, anthelmintic, phytotoxic, analgesic effects [16-25].

Extracts are used to allay pain and irritation, clean wounds and ulcers and aid prevention, as well as therapy for irradiated skin injuries, treatment of cystitis and dental afflictions. Some species of Anthemis are being used as

Mustafayeva Sitara Jalal - Leading scientist, candidate of biological sciences (Ph.D), assistant of professor, Plant resources department, e-mail: s.serkerov@mail.ru Serkerov Sirajeddin Veli - Doctor, Professor, Plant resources department, e-mail: s.serkerov@mail.ru

Bakhshaliyeva Konul Farrukh - Doctor, assistant of professor, Head of laboratory of "Microbiological

Biotechnology", e-mail: s.serkerov@mail.ru herbal tea to cure anxiety, flatulence stomach disorders and carminative infusions [20].

13 species of Anthemis are spread in Azerbaijan [26]. The species are spread mainly in dry clay, stony and torn slopes, in sandy places, clay stones, grasslands, rocks, on stony traps, and sometimes on a

\footnotetext{
* Corresponding author.
} 
weed. Some species are known as medicines, decorative, dyes and insecticides plants. Antibacterial, antimicrobial and antifungal properties of these species are also known [6,21].

As known the plants we use for different purposes (medicines, decorative, food, etc.) are also a good media for many bacteria and fungi. Thus, different mushrooms populate on plants that are favorable to them and cause pathogens to the plant. The intensive development of the disease depends on the interaction of the plant and pathogen with one another (plant resistance), but also on the environment. Diseases caused by fungi weaken the plant by infecting separate plant organs, and ultimately, the plant's total destruction. It should be noted that physiological and structural abnormalities in the herb have a great impact on its productivity. Sometimes the plant has a selective feature, thanks to the biological active compounds contained in the plants, and in particular, prevents any fungus from populating itself, which is antimicrobial.

The literature contains a fairly large number of research papers devoted to the study of the antifungal activity of various plant species (Funtumia elastica, Mallotus oppositifolius, Trachystemon orientalis, Smilax excelsa, Rhododendron ponticum, Phytolacca Americana, Prunus laurocerasus, Artemisia herba alba, Cotula cinerea, Asphodelus tenuifolius, Euphorbia guyoniana and etc.) and extracts, essential oils, saponins, flavonoids, and other biologically active substances obtained from them [27-30].

Considering the beneficial properties of species of the genus Anthemis, we decided to investigate the chemical composition and antifungal properties of Anthemis altissima L. (syn. Cota altissima (L.) J.Gay), common in the territory of Azerbaijan.

In composition A. altissima identified of essential oils, sesquiterpenoids, steroids, aliphatic carbohydrates, aromatic compounds, high fatty acids, aldehydes, ketones, phenolcarbonic acids and others chemical components [6].

\section{Materials and methods}

The investigated materials were the above-ground part of species A. altissima. They were gathered in flowering phase in the village Avaxil of Shamakhi region, Pirqulu settlement, Pirsaat river, yard areas and grassland, as well as Shamakhi city. Here A. altissma forms large spots with an abundance mark of 3 among the forbs.

A. altissima is annual plant with a height of 20-80 sm. The leaves are oblong egg-shaped. The basket are one by one. The flowers are white. Seeds are light-brown and compressed. Flowering time of plant from May to July, seeds - June to August.

A. altissima is found everywhere in Azerbaijan except Nakhchivan. From lowland to middle mountain range, it spreads along the road between fields, plantings, gardens, bushes and grass stones. Weed, forest-meadow is a representative of plant species. It is xeromezophyte plant. Geographical type - xerophytes, class - intermediate sea [31].

The harvested plant material of the above-ground part of Aaltissima was dried and crushed. The $300 \mathrm{~g}$ of plant raw material A. altissima was extracted in 3 days 3 times with 95\% ethanol (alcohol) 3 times a day.

The chemical composition of ethanol extract of A. altissima was analyzed by using chromatography-massspectrometry methods.

The component composition of the obtained plant extract $A$. altissima was investigated by gas chromatography-mass spectrometry (GC/MS) on an Agilent Technologies gas chromatograph 6890N Network CG System, 5975 inert Mass Selective Detector mass spectrometer as a Split/Splitless detector, Injection - Split, Inlet pressure $60.608 \mathrm{kPa}$, Split/ Splitless detector 100 Low Mass - 40, High Mass - 400, Thresold 150. A 30-meter capillary quartz column "HP-5MS 5\% Metil Siloxane" with an internal diameter of $0.25 \mathrm{~mm}$ and a slick of a stationary phase of $0.25 \mu$ was used. Analyzes were carried out in temperature programming mode from $50^{\circ} \mathrm{C}$ to $280^{\circ} \mathrm{C}$ at a speed of $15^{\circ} \mathrm{C} / \mathrm{min}$. Column temperature: initial temperature $50^{\circ} \mathrm{C}-2$ minutes is stable; raising the temperature $15{ }^{\circ} \mathrm{C} / \mathrm{min}$. up to $200^{\circ} \mathrm{C}-6$ minutes stable; raising the temperature $15^{\circ} \mathrm{C} / \mathrm{min}$. up to $280^{\circ} \mathrm{C}-10$ minutes stable. Vacuum - HiVac $-3.38 \times 10^{-5}$. Extract diluted with methanol : chloroform $(1: 2)$.Velocity of carrier gas $(\mathrm{He})$ $1 \mathrm{ml} / \mathrm{min}$. Input samples with current division $(1: 50)$. The analysis time is 45 minutes. To identify the connection using the standard mass spectrometric library NIST (the NIST Mass Spectral Seach Proqramfo the NIST/EPA/NIH/Mass Spectral Library Version 2.0.g.buld May 19 2011) [32].

The antifungal activity of the A. altissima and aqueous extracts obtained from them was studied by conventional methods against the culture of microscopic pathogenic fungi Fusarium oxysporum and Aspergillus niger, stored in the museum of the Institute of Microbiology ANAS [33]. 
Antifungal activity was measured in two steps as follows: development of fungus in solid media and development of fungus in aqueous extract of different concentrations from A. altissima.

Development of fungi in solid media. The material obtained from dried A. altissima plants was ground into small pieces of 0.5 to $1 \mathrm{~cm}$ in size and wetted with 55-60\% water. Therefore, fungi can develop in a solid medium. The $\mathrm{pH}$ level was relatively constant in the range of 6.5 to 7 . The substrate, widely washed with culture, was placed in Petri dishes and sterilized at $1 \mathrm{~atm}$ pressure for 45 minutes. After sterilization, the fungal biomass was also inoculated into Petri dishes and incubated at $25-27^{\circ} \mathrm{C}$. The number of colonies was performed on each of the dishes 3 , 5 and 7 days after the inoculation.

The development of fungi in different extracts. For study antifungal effects of extracts from aboveground parts species $A$. altissima was taken various coagulation extracts $(5,10,15 \mathrm{q})$ and it has been heated. The extraction pour into glass bottles. Then, extraction was cooled, filtered and poured into glass bottles. It was sterilized at $0.5 \mathrm{~atm}$ pressure for 30 minutes. The test was conducted at $\mathrm{pH}$ levels of 6, 5 and 7. Fungi strains were inoculated into extract inside a test tube. Then they were incubated at $25-27^{\circ} \mathrm{C}$ for seven days. Czapek's media was used for comparing results.

\section{Experimental part}

As mentioned above, 300 grams of plant raw material A. altissima was extracted with ethanol and total of 26 grams of extractable ingredients were obtained, which means $8.7 \%$ of the production. It was identified 54 components from the ethanol extract of the A. altissima by using chromato-mass-spectroscopy method. The results are given in the table.

As can be seen from the table, the extract contains aromatic compounds, alcohols, acids, alkanes, lactone, coumarine, triterpenoids and terpenes. Preference is given to benzene-cyclic aromatic compounds $-77.21 \%$. Among them are Benzene, (1-butylheptyl) - 7.84\%, Benzene, (1-propyloctyl) - 7.71\%, Benzene, (1-pentyloctyl) - 7.03\%, Benzene, (1-pentylheptyl) - 5.69\%, Benzene, (1-butyloctyl) - 5.37\%, Benzene, (1-propylnonyl) - 5.02\% the main components.

In addition to the above components in the extract of the aerial part other biological active substances, such as alcohols $(6.37 \%$ - of them prevail Hop-22(29)-en-3 $\beta$-ol - 1.53\%, $\gamma$-Sitosterol $-1.32 \%)$, esters of acids $(5.3 \%-$ of them prevail Hexadecanoic acid, ethyl ester $0.88 \%$; Linoleic acid, ethyl ester $0.63 \%)$ and alkanes $(1.64 \%-$ of them prevail Eicosane $-0.53 \%$; Pentacosane $-0.40 \%$ ) have been identified. The share of unidentified components was $8.99 \%$.

As we noted $A$. altissima species antifungal activity was measured in two steps as follows: development of fungus in solid media and development of fungus in aqueous extract of different concentrations from A. altissima.

Figure 1 shows the results of the growth of phytopathogen fungi Fusarium oxysporum and Aspergillus niger on A. altissima.

As shown in figure 1 in solid food environment consisting of $A$. altissima, the size of fungal colonies of Fusarium oxysporium on 3-rd day were $1.0 \mathrm{sm}, 5$-th day 2.6, and 7-th day $5.6 \mathrm{sm}$, the colonies of Aspergillus niger fungi, respectively, were $4.2 ; 6.9 ; 8.0 \mathrm{sm}$.

The control options size of fungi colonies was $8.0 \mathrm{sm}$.

Thus, the results show that aboveground parts A. altissima can not be used as an antifungal vehicle.

When analyzing literature sources, we encountered similar studies on the antifungal activity of water extract of $A$. altissima. Aqueous extract A. altissima growing in the Kermanshah acts antifungal against Phytophthora drechsleri and prevented the growth [28]. Out of 54 identified components of the extract, 20 components make up the aromatic compounds. besides, among the components found in the extract there are no compounds that are contained in large quantities, and therefore it is not possible to connect the antifungal properties with any predominant components. According to our assumptions, the antifungal activity of the extract is probably due to the synergistic active components of the aromatic compounds.

Figure 2 presents the results of the effect of different concentrations of water extract of $A$. altissima on the development of the fungi Fusarium oxysporum and Aspergillus niger.

Thus, as shown in Figure 2, the aqueous extract of $A$. altissima in different concentrations $(5,10,15 \mathrm{~g})$ had a fungistatic effect on both fungi (Fusarium oxysporium and Aspergillus niger), inhibition was observed to one degree or another. In contrast to the control $(5.12-5.52 \mathrm{~g} / \mathrm{l})$, biomass ranged from 0.09 to $0.58 \mathrm{~g} / \mathrm{l}$.

The results obtained from the aqueous extracts of $A$. altissima can be used in the preparation of new antifungal drugs. 
The content of etanol extract of the above-ground part of Anthemis altissima

\begin{tabular}{|c|c|c|c|c|}
\hline No. & $\begin{array}{l}\text { Retention } \\
\text { time }\end{array}$ & Name of the compound & $\begin{array}{l}\text { Molecular for- } \\
\text { mula }\end{array}$ & Peak $(\%)$ \\
\hline 1 & 7.169 & 2-Hydroxy-gamma-butyrolactone & $\mathrm{C}_{4} \mathrm{H}_{6} \mathrm{O}_{3}$ & 1.44 \\
\hline 2 & 8.216 & Thymine & $\mathrm{C}_{5} \mathrm{H}_{6} \mathrm{~N}_{2} \mathrm{O}_{2}$ & 0.49 \\
\hline 3 & 8.492 & Butanoic acid, 3-amino- & $\mathrm{C}_{4} \mathrm{H}_{9} \mathrm{NO}_{2}$ & 0.60 \\
\hline 4 & 9.039 & 4H-Pyran-4-one, 2,3-dihydro-3,5-dihydroxy-6-methyl- & $\mathrm{C}_{6} \mathrm{H}_{8} \mathrm{O}_{4}$ & 0.67 \\
\hline 5 & 9.516 & Catechol & $\mathrm{C}_{6} \mathrm{H}_{6} \mathrm{O}_{2}$ & 0.24 \\
\hline 6 & 9.775 & Benzofuran, 2,3-dihydro- & $\mathrm{C}_{8} \mathrm{H}_{8} \mathrm{O}$ & 0.17 \\
\hline 7 & 11.557 & Naphthalene, 2-methyl- & $\mathrm{C}_{11} \mathrm{H}_{10}$ & 0.45 \\
\hline 8 & 11.851 & 2,1,3-Benzothiadiazole & $\mathrm{C}_{6} \mathrm{H}_{4} \mathrm{~N}_{2} \mathrm{~S}$ & 1.16 \\
\hline 9 & 12.098 & Silane, dimethyl(4-acetylphenoxy)isobutoxy- & $\mathrm{C}_{14} \mathrm{H}_{22} \mathrm{O}_{3} \mathrm{Si}$ & 1.42 \\
\hline 10 & 12.692 & Benzene, (1-butylhexyl)- & $\mathrm{C}_{16} \mathrm{H}_{26}$ & 1.29 \\
\hline 11 & 12.780 & Benzene, (1-propylheptyl)- & $\mathrm{C}_{16} \mathrm{H}_{26}$ & 0.97 \\
\hline 12 & 12.951 & Benzene, (1-ethyloctyl)- & $\mathrm{C}_{16} \mathrm{H}_{26}$ & 1.24 \\
\hline 13 & 13.133 & Sorbitol & $\mathrm{C}_{6} \mathrm{H}_{14} \mathrm{O}_{6}$ & 0.82 \\
\hline 14 & 13.263 & Benzene, (1-methylnonyl)- & $\mathrm{C}_{16} \mathrm{H}_{26}$ & 2.00 \\
\hline 15 & 13.374 & Benzene, (1-pentylheptyl)- & $\mathrm{C}_{18} \mathrm{H}_{30}$ & 0.25 \\
\hline 16 & 13.521 & Benzene, (1-butylheptyl)- & $\mathrm{C}_{17} \mathrm{H}_{28}$ & 7.84 \\
\hline 17 & 13.621 & Benzene, (1-propyloctyl)- & $\mathrm{C}_{17} \mathrm{H}_{28}$ & 7.71 \\
\hline 18 & 13.839 & Benzene, (1-ethylnonyl)- & $\mathrm{C}_{17} \mathrm{H}_{28}$ & 3.60 \\
\hline 19 & 14.221 & Benzene, (1-methyldecyl)- & $\mathrm{C}_{17} \mathrm{H}_{28}$ & 3.87 \\
\hline 20 & 14.304 & Bicyclo[6.3.0]undeca-1(8),9-diene, 11,11-dimethyl- & $\mathrm{C}_{13} \mathrm{H}_{20}$ & 0.24 \\
\hline 21 & 14.439 & Benzene, (1-pentylheptyl)- & $\mathrm{C}_{18} \mathrm{H}_{30}$ & 5.69 \\
\hline 22 & 14.492 & Benzene, (1-butyloctyl)- & $\mathrm{C}_{18} \mathrm{H}_{30}$ & 5.37 \\
\hline 23 & 14.639 & Benzene, (1-propylnonyl)- & $\mathrm{C}_{18} \mathrm{H}_{30}$ & 5.02 \\
\hline 24 & 14.915 & Benzene, (1-ethyldecyl)- & $\mathrm{C}_{18} \mathrm{H}_{30}$ & 4.23 \\
\hline 25 & 15.421 & Benzene, (1-methylundecyl)- & $\mathrm{C}_{18} \mathrm{H}_{30}$ & 4.74 \\
\hline 26 & 15.645 & Benzene, (1-pentyloctyl)- & $\mathrm{C}_{19} \mathrm{H}_{32}$ & 7.03 \\
\hline 27 & 15.739 & Benzene, (1-butylnonyl)- & $\mathrm{C}_{19} \mathrm{H}_{32}$ & 4.79 \\
\hline 28 & 15.939 & Benzene, (1-propyldecyl)- & $\mathrm{C}_{19} \mathrm{H}_{32}$ & 3.85 \\
\hline 29 & 16.315 & Benzene, (1-ethylundecyl)- & $\mathrm{C}_{19} \mathrm{H}_{32}$ & 3.55 \\
\hline 30 & 16.939 & Benzene, (1-methyldodecyl)- & $\mathrm{C}_{19} \mathrm{H}_{32}$ & 3.45 \\
\hline 31 & 17.692 & Scopoletin & $\mathrm{C}_{10} \mathrm{H}_{8} \mathrm{O}_{4}$ & 0.38 \\
\hline 32 & 18.151 & Hexadecanoic acid, ethyl ester & $\mathrm{C}_{18} \mathrm{H}_{36} \mathrm{O}_{2}$ & 0.88 \\
\hline 33 & 19.992 & Phytol & $\mathrm{C}_{20} \mathrm{H}_{40} \mathrm{O}$ & 0.72 \\
\hline 34 & 20.786 & Linoleic acid ethyl ester & $\mathrm{C}_{20} \mathrm{H}_{36} \mathrm{O}_{2}$ & 0.63 \\
\hline 35 & 20.874 & Ethyl 9,12,15-octadecatrienoate & $\mathrm{C}_{20} \mathrm{H}_{34} \mathrm{O}_{2}$ & 0.62 \\
\hline 36 & 22.827 & 3-Oxatricyclo [4.1.1.0 (2,4)] octane, 2,7,7-trimethyl- & $\mathrm{C}_{10} \mathrm{H}_{16} \mathrm{O}$ & 0.25 \\
\hline 37 & 22.903 & Heptadecane & $\mathrm{C}_{17} \mathrm{H}_{36}$ & 0.39 \\
\hline 38 & 23.550 & 3-Cyclohexene-1-methanol, 6-methyl & $\mathrm{C}_{8} \mathrm{H}_{14} \mathrm{O}$ & 1.08 \\
\hline 39 & 24.162 & Benzylcarbamate & $\mathrm{C}_{8} \mathrm{H}_{9} \mathrm{NO}_{2}$ & 0.84 \\
\hline 40 & 24.421 & Phenol, 2,2'-methylenebis[6-(1,1-dimethylethyl)-4-methyl- & $\mathrm{C}_{23} \mathrm{H}_{32} \mathrm{O}_{2}$ & 0.35 \\
\hline 41 & 24.556 & 2,3,4-Trimethylpyrrole & $\mathrm{C}_{7} \mathrm{H}_{11} \mathrm{~N}$ & 0.85 \\
\hline 42 & 25.709 & Pentacosane & $\mathrm{C}_{25} \mathrm{H}_{52}$ & 0.40 \\
\hline 43 & 25.815 & $\begin{array}{l}\text { Hexadecanoic acid, 2-hydroxy-1-(hydroxymethyl) ethyl es- } \\
\text { ter }\end{array}$ & $\mathrm{C}_{19} \mathrm{H}_{38} \mathrm{O}_{4}$ & 0.59 \\
\hline 44 & 26.079 & Phthalic acid, di(2-propylpentyl) ester & $\mathrm{C}_{24} \mathrm{H}_{38} \mathrm{O}_{4}$ & 0.51 \\
\hline 45 & 28.103 & 9,12-Octadecadienoic acid (Z,Z)-2,3-dihydroxypropyl ester & $\mathrm{C}_{21} \mathrm{H}_{38} \mathrm{O}_{4}$ & 0.36 \\
\hline 46 & 28.209 & Linolenic acid, 2-hydroxyl- (hydroxymethyl) ethyl ester & $\mathrm{C}_{21} \mathrm{H}_{36} \mathrm{O}_{4}$ & 0.46 \\
\hline 47 & 28.285 & Heneicosane & $\mathrm{C}_{21} \mathrm{H}_{44}$ & 0.32 \\
\hline 48 & 29.432 & Decanedioic acid, bis(2-ethylhexyl) ester & $\mathrm{C}_{26} \mathrm{H}_{50} \mathrm{O}_{4}$ & 0.30 \\
\hline 49 & 30.661 & Eicosane & $\mathrm{C}_{20} \mathrm{H}_{42}$ & 0.53 \\
\hline 50 & 35.544 & Stigmasterol & $\mathrm{C}_{29} \mathrm{H}_{48} \mathrm{O}$ & 0.57 \\
\hline 51 & 36.726 & $\gamma$-Sitosterol & $\mathrm{C}_{2}{ }_{2} \mathrm{H}_{50} \mathrm{O}$ & 1.32 \\
\hline 52 & 37.561 & $\beta$-Amyrin & $\mathrm{C}_{30} \mathrm{H}_{50} \mathrm{O}$ & 0.62 \\
\hline 53 & 40.743 & Taraxasterol & $\mathrm{C}_{30} \mathrm{H}_{50} \mathrm{O}$ & 0.82 \\
\hline 54 & 41.049 & Hop-22(29)-en-3 $\beta$-ol & $\mathrm{C}_{30} \mathrm{H}_{50} \mathrm{O}$ & 1.53 \\
\hline
\end{tabular}




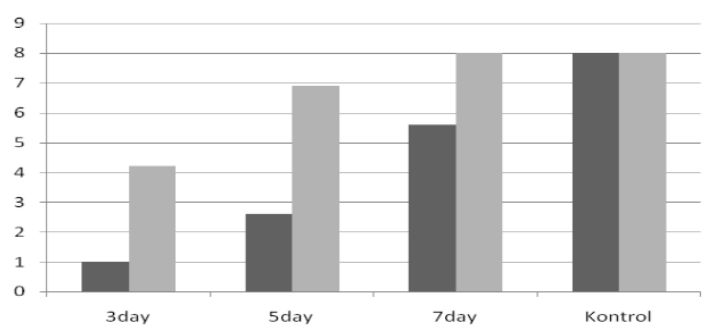

Fig. 1. Development processes for Fusarium oxysporum and Aspergillus niger colonies in solid media prepared with $A$. Altissima by abscissa developments of colonies fungus, sm; by horizontals days

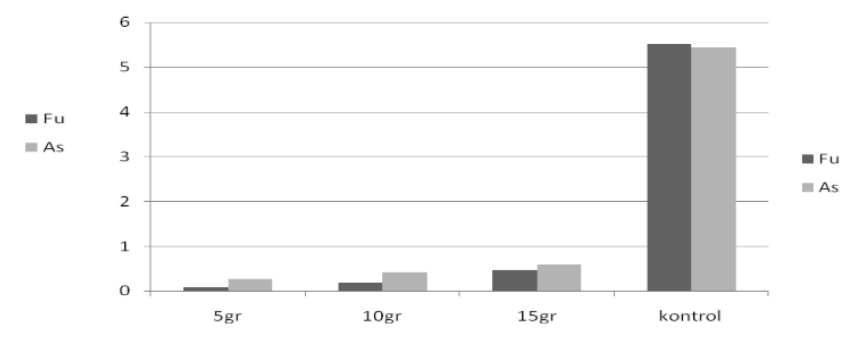

Fig. 2. Effects of extracts from A. altissima on Fusarium oxysporum and Aspergillus niger fungal colonies by abscissa - dry biomass, q/1; by horizontals - aqueous extact

\section{Conclusion}

1. The above-ground part of species A. altissima were gathered in flowering phase from the village Avaxil of Shamakhi region, Pirqulu settlement, Pirsaat river, yard areas and grassland, as well as Shamakhi city.

2. After ethanol extracting of $300 \mathrm{~g}$ of $A$. altissima plant, was obtained $26 \mathrm{~g}$ of extractable ingredients, which means $8.7 \%$ of output.

3. 54 components from the ethanol extract of the A. altissima were identified by the chromato-mass-spectroscopy method.

4. The extract of $A$. altissima contains aromatic compounds, alcohols, esters of acids, alkanes, lactone, coumarine and terpenes. Preference is given to benzene-cyclic aromatic compounds $-77.21 \%$. Among them Benzene, (1-butylheptyl) - 7.84\%, Benzene, (1-propyloctyl) - 7.71\%, Benzene, (1-pentyloctyl) - 7.03\% are the main components. Of the identified components can be also noted alcohols $(6.37 \%)$, esters of acids $(5.3 \%)$, and alkanes $(1.64 \%)$. The share of unidentified components was $8.99 \%$.

5. Unlike the control variant, water extracts of A. altissima have a rather high fungistatic effect on the pathogenic fungi Fusarium oxysporium and Aspergillus niger, which allows them to be used for the preparation of new antifungal drugs.

\section{References}

1. Al-Humaidi J. Oriental J. Chem., 2015, vol. 31, no. 4, pp. 2265-2270.

2. Konstantinopoulou M., Karioti A., Skaltsas S., Skaltsa H. J. Nat. Prod., 2003, vol. 66, pp. 699-702. DOI: $10.1021 / \mathrm{np} 020472 \mathrm{~m}$.

3. Masterova I., Grancai D., Grancaiova Z., Pour M., Ubik K. Pharmazie, 2005, vol. 60 pp. 956-957.

4. Pavlovic M., Kovacevic N., Tzakou O., Couladis M. Chem. Nat. Compd., 2007, vol. 43, pp. $512-514$. DOI: $10.1007 / \mathrm{s} 10600-007-0179-\mathrm{x}$

5. Vuckovic I., Vujusic L., Milosavljevic S. Serb. Chem. Soc., 2005, vol. 71, pp. 127-133.

6. Rastitel'nyye resursy Rossii: dikorastushchiye rasteniya, ikh komponentnyy sostav i biologicheskaya aktivnost'. [Plant resources of the Russia: Wild flowering plants, their component composition and biological activity]. St. Petersburg, Moscow, 2012, vol. 5, 317 p. (in Russ.).

7. Vujisic L., Vuckovic I., Vajs V., Tesevic V., Janackovic P., Milosavljevic S. Chemistry of Natural Compounds, 2011, vol. 47, no. 3, p. 459.

8. Staneva J.D., Trendafilova-Savkova A., Todorova M.N., Evstatieva L.N., Vitkova A. Z. Naturforsch. C., 2004, vol. 59, no. 3-4, pp.161-165.

9. Saroglou V., Dorizas N., Kypriotakis Z., Skaltsa H.D. J. Chromatogr. A, 2006, vol. 1104, no. 1-2, pp. 313-322, DOI: $10.1016 /$ j.chroma.2005.11.087.

10. Rezaee M.B., Jaimand K., Assareh M.H. Iranian Journal of Pharmaceutical Research, 2004, vol. 3, suppl. 2, p. 89.

11. Rezaee M.B., Jaimand K., Assareh M.H. Journal of Essential Oil Research, 2006, vol. 18, no. 2, pp. $152-153$.

12. Rezaee M.B., Jaimand K. Journal of Essential Oil Research, 2008, vol. 20, no. 2, pp. 172-173.

13. Rezaee M.B., Jaimand K. Faslnamah-I Giyahan-I Daruyi., 2007, vol. 6, no. 22, pp. 99-105; Chem. Abstr., 2009, vol. 150, no. 393461.

14. Pavlović M., Kovačević N., Tzakou O., Couladis M. Flavour and Fragrance Journal, 2006, vol. 21, no. 2, pp. $297-$ 299, DOI: $10.1002 /$ ffj. 1592 
15. Hanganu D., Pintea A., Marculescu A., Toma C., Mirel S. Farmacia, 2008, vol. 56, no. 3, pp. 344-351.

16. Amjad L., Madani M., Rezvani Z. World Acad. Sci. Eng. Technol., 2012, vol. 61, pp. 901-902.

17. Burim R.V., Canalle R., Lopes J.L.C., Takahashi C.S. Genet. Mol. Biol., 1999, vol. 22, pp. 401-406, DOI: $10.1590 /$ S1415-47571999000300020.

18. Hajdu Z., Zupko I., Rethy B., Forgo P., Hohmann J. Planta Med., 2010, vol. 76, pp. 94-96.

19. Papaioannoua P., Lazaria D., Kariotib A., Soulelesa C., Heilmannc J., Hadjipavlou-Litinad D., Skaltsab H. Z. Naturforsch., 2007, vol. 62, pp. 326-330.

20. Vakili E., Amjad L., Karbasizade V. Int. J. Agric. Crop Sci., 2013, vol. 5, pp.1464-1467.

21. Mustafayeva S.J., Bakhshaliyeva K.F. Materialy V mezhdunarodnoy nauchnoy konferentsii «Printsipy $i$ sposoby sokhraneniya bioraznoobraziya». [Materials V Int. Scientific. conf., "Principles and retain of Biodiversity Conservation"], Yoshkar-Ola, 2013, pp. 280-284. (in Russ.).

22. Vuckovic I., Vujisic L., Klaas C.A., Merfort I., Milosavljevic S. Nat. Prod. Res., 2011, vol. 25, no. 8, pp. 800-805.

23. Samadi N., Manayi A., Vazirian M., Samadi M., Zeinalzadeh Z., Saghari Z., Abadian N., Mozaffarian V.O-A., Khanavi M. Natural Product Research: Formerly Natural Product Letters, 2012, vol. 26, no. 20, pp. 1931-1934.

24. Quarenghi M.V., Tereschuk M.L., Baigori M.D., Abdala L.R. Fitoterapia, 2000, vol. 71, no. 6, pp. 710-712.

25. Akgul C., Saglikoglu G. Indian J. Biochem. Biophys., 2005, vol. 41, no. 6, pp. 395-397.

26. Mustafayeva S.C. News ANAS (Biology and Medical Sciences), 2013, vol. 68, no. 1, pp. 17-23.

27. Adekunle1 A.A, Ikumapayi A.M. West Indian Med. J., 2006, vol. 55, no. 4, pp. 219-223, DOI: 10.1590/S004331442006000400003.

28. Abdolmaleki M., Bahraminejad S., Abbasi S. J. Med. Plant., 2011, vol. 10, no. 38, pp. 148-155.

29. Satish S., Raghavendra M.P., Raveesha K.A. Journal Archives of Phytopathology and Plant Protection, 2009, vol. 42, no. 7, pp. 618-625, DOI: 10.1080/03235400701287578.

30. Nasrine S., Sultan A., Mohammed S., Valeria T., Iman B., Naima G., Samia B. Biomed. Res. Int., 2017, vol. 2017, article 7526291, DOI: 10.1155/2017/7526291.

31. Flora Azerbaydzhana. [Flora of Azerbaijan]. Baku, 1961, vol. VIII, pp. 248-265. (in Russ.).

32. Adams R.P. Identification of Essential oil Components by Gas chromatography / Mass Spectroscopy, Alluned Publishing Corp., Carol Stream, IL, USA, 2007, 803 p.

33. Metody eksperimental'noy mikologii. [Methods of experimental mycology], ed. V.I. Bilai, Kiev, 1982, 500 p. (in Russ.).

Received March 11, 2019

Revised May 20, 2019

Accepted May 27, 2019

For citing: Mustafayeva S.J., Serkerov S.V., Bakhshaliyeva K.F. Khimiya Rastitel'nogo Syr'ya, 2019, no. 4, pp. 129134. (in Russ.). DOI: 10.14258/jcprm.2019045267. 